\title{
MATHEMATICAL MODEL FOR FORMATION OF SPUR GEAR TEETH BY A HYPERBOLIC REFERENCE PROFILE
}

The aim of this work is to create a fundamentals of mathematical model which consists in definition of geometry of a generating surface and machining gearing for novel cylindrical spur transmission. The generating surface is considered as rack-cutter with teeth, which profiled by hyperbola - a curve which is smooth at whole addendum and dedendum parts of reference profile. The equations of teeth surfaces which help the basic performances of this generating surface surveyed, namely quadratic forms and normal curvatures in the given directions are presented. The equations of machining gearings which help to obtain the equations of surfaces of teeth which can be applied both for working surfaces and for their fillets are obtained. For these surfaces quadratic forms also defined. Boundaries of a contact zone are defined. The results obtained in a paper can be used for definition of quality indicators of serviceability of novel transmissions which will allow carrying out a comparative estimation of novel transmission with conventional one and with other types of transmissions.

Keywords: cylindrical spur gearing, hyperbolic reference profile, generating surface, rack-cutter, cutting meshing.

\section{П. М. ТКАЧ, П. Л. НОСКО, О. О. РЕВЯКІНА, О. В. БАШТА, А. О. КОРНІСНКО, О. В. ТІСОВ, Ю. О. ЦИБРІЙ МАТЕМАТИЧНА МОДЕЛЬ УТВОРЕННЯ ЗУБЦІВ ЦИЛІНДРИЧНОЇ ПРЯМОЗУБОЇ ПЕРЕДАЧІ ГІПЕРБОЛІЧНИМ ВИХІДНИМ КОНТУРОМ}

Представлено теоретичне дослідження внутрішньої геометрії виробної поверхні та верстатного зачеплення для утворення зубців циліндричних прямозубих передач нового типу. Виробна поверхня розглядається як інструментальна рейка 3 вихідним контуром, що спрофільовано гіперболою. Наведено рівняння поверхонь зубців інструментальної рейки, розглянуто основні характеристики цієї виробної поверхні, а саме квадратичні форми і нормальні кривизни в заданих напрямках. Представлено рівняння верстатного зачеплення, за допомогою якого одержано рівняння поверхонь зубців, як робочих так і перехідних. Для цих поверхонь також визначено коефіцієнти квадратичних форм та кривизни. Визначено межі поля зачеплення. Результати, одержані в статті, в подальшому можна використовувати для визначення якісних показників працездатності нового типу передач, що дозволить проводити їх порівняльну оцінку із традиційними та іншими видами передач.

Ключові слова: циліндрична прямозуба передача, гіперболічний вихідний контур, виробна поверхня, інструментальна рейка, верстатне зачеплення.

\section{П. Н. ТКАЧ, П. Л. НОСКО, О. А. РЕВЯКИНА, А. В. БАШТА, А. А. КОРНИЕНКО, А. В. ТІСОВ, Ю. А. ЦИБРИЙ МАТЕМАТИЧЕСКАЯ МОДЕЛЬ ОБРАЗОВАНИЯ ЗУББЕВ ЦИЛИНДРИЧЕСКОЙ ПРЯМОЗУБОЙ ПЕРЕДАЧИ ГИПЕРБОЛИЧЕСКИМ ИСХОДНЫМ КОНТУРОМ}

Представлено теоретическое исследование внутренней геометрии производящей поверхности и станочного зацепления для образования зубьев цилиндрических прямозубых передач нового типа. Производящая поверхность рассматривается как инструментальная рейка с исходным контуром, спрофилированным гиперболой. Представлены уравнения поверхностей зубьев инструментальной рейки, с помощью которых рассмотрены основные характеристики этой производящей поверхности, а именно квадратичные формы и нормальные кривизны в заданных направлениях. Получены уравнения станочного зацепления, с помощью которых выведены уравнения поверхностей зубьев, которые могут быть применены как для рабочих поверхностей зубьев, так и для переходных. Для этих поверхностей также определены квадратичные формы и кривизны. Определены границы поля зацепления. Результаты, полученные в статье, в дальнейшем можно использовать для определения качественных показателей работоспособности нового типа передач, что позволит проводить их сравнительную оценку с традиционными и другими видами передач.

Ключевые слова: цилиндрическая прямозубая передача, гиперболический исходный контур, производящая поверхность, инструментальная рейка, станочное зацепление.

Introduction. Gear transmissions are one of the most important parts of machines and mechanisms. The gears due to their positive properties are the most common and promising. It is confirmed by the constant growth of the world volume of their production by $4-6 \%$ according to the data $[1,2]$. A very optimistic forecast for 2018 was obtained from the results of an annual survey by the Gear Technology magazine [3]. That's why, researches which aimed to improving the quality performance of gear transmissions have great importance for the machinebuilding industry. Therefore, the improving of gear transmissions is, of course, a relevant objective.

Analysis of the literature. The promising method to improve gears is the selection of rational geometric parameters, which will allow the improvement of qualitative indicators without changing the materials, overall dimensions and accuracy. Significant success in the implementation of this method has been achieved in relation to conventional (involute) gears. This direction of research became relevant in the seventies of the last century $[4,5]$ and it continues to developing to nowadays $[6,7]$. Practical implementation of this method is limited. First, the contact loading capacity of the involute gear is limited by the high value of the relative curvature of the teeth, which is furthemore depends of the wheels radii. Secondly, the bending loading capacity can not be increased significantly by the fillet modification due to fillet location within the radial clearance. Therefore, we can assume that conventional transmissions have insignificant reserves for further improvement.

In recent decades, Ukrainian researchers have been offered a range of new gears that are alternatives to traditional ones. These are evolute transmissions [8, 9], "enkaitic" [10], C-C transmissions $[11,12]$, transmission which are synthesized according to serviceability indicators [13-15], transmission with increased load capacity, which basic rack is profiled by algebraic and transcendental curves [16-18]. The new types of gearing proposed in works [8-18] have good perspectives for further implementation into industry due to the development of new highly effective methods of gear machining [19-21]. The peculiarity of works [8-18] is 
the focus on increasing the contact strength, so the main attention is given to the working area of the reference profile. The fillet area is considered separately, and it is defined by another curve, which is tangent to the working segment. This approach creates the technological difficulties, in particular when a cutting tool is designed. A new approach, which consist in simultaneously determine the shape of both sections of the profile as a solution to a single problem, is proposed in [22] for the formation of the reference profile. This approach was successfully implemented by the authors [23] by means of spline-interpolation of the reference profile by Bezier's curves. In this case, the profile is set in the form of a point diagram, and the equations describing the reference profile are polynomials of the third degree. This approach provides advantages in modeling of formation, but it complicates the mathematical description of the quality indicators of transmissions. A compromise in this case is to use as a profile the sine curve [24] or the conic curves. Possibility of conic curves using to profiling the basic rack is established in [25]. In particular, it was found in [25] that the gears which are generated by the hyperbolic reference profile can be used as an alternative for the most common involute gearing with a $20^{\circ}$ profile angle and a 1.25 height ratio.

The purpose of the article. The article aims to create a basis for the mathematical model of the teeth formation by a hyperbolic reference profile, in particular the study of the internal geometry of the generating surface and machining gearing, which will further allow to determine the quality performance of such transmissions.

Statement of the research task. The basis of the generating surface is the hyperbolic profile (Fig. 1), because it forms a normal section of surface (Fig. 2). It should be noted that the hyperbolic reference profile, unlike the involute, is continuous in the segment from the pitch line (indicated by p.l. in Fig. 1) to the tip of the tooth ( $O_{r} A$ segment in Fig. 1). The segment from the pitch line to the line of profile valleys $O_{r} D$ is symmetric to $O_{r} A$. It makes possible to consider both of the active part and the root fillet which will be described by one function within the one mathematical model. To do it, we can use only the top part of the profile $O_{r} A$, the dedendum $O_{r} D$ is symmetric to $O_{r} A$ relative $O_{r}$. The generating surface will be considered as a rack-type tool.

1. Hyperbolic reference profile. Let's define the coordinate system, which is connected with the profile. In this case, the axis $O_{r} Y_{r}$ is directed along the pitch line of the tooth of the basic rack (Fig. 1).

The coordinates of the profile are

$$
x_{r}=\lambda ; y_{r}=\frac{\pi}{4}-b \sqrt{\theta^{2}+2 \theta},
$$

where $\lambda$ - variable which determines the position of the profile point in height (Fig. 1);

$\theta$-geometric parameter which is equal to

$$
\theta=\frac{h-\lambda}{a}
$$

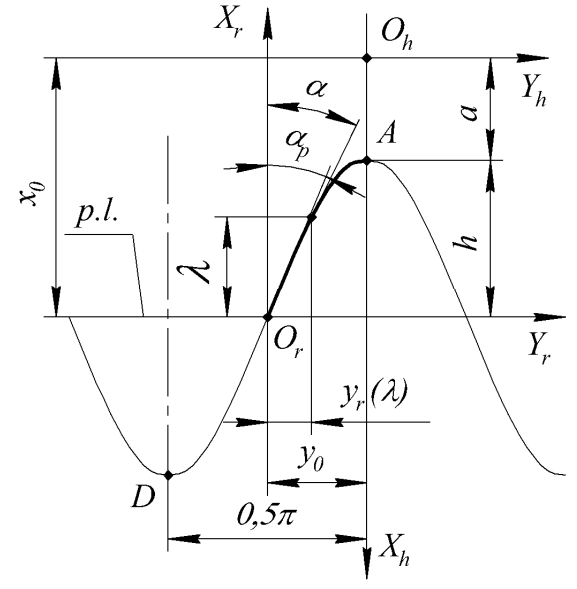

Fig. 1 - The main parameters of the hyperbolic reference profile

$h$ - the height of the profile (Fig. 1), which is equal $h_{a} m$ for addendum and $h_{f} m$ and for dedendum $\left(h_{a}\right.$ and $h_{f}$ are the addendum and dedendum coefficients of reference profile). Here and elsewhere was accepted the value of the module $m=1 \mathrm{~mm}$. To study transmissions with another value of module it is necessary in equations (1) and elsewhere coordinates $x_{r}$ and $y_{r}$ multiply by $m$;

$a$ and $b$ - real and imaginary semi-axes of hyperbola respectively [25],

$$
\begin{gathered}
a=\frac{\pi h-4 h^{2} \operatorname{tg} \alpha_{p}}{8 h \operatorname{tg} \alpha_{p}-\pi} ; \\
b=\frac{\pi}{4 \sqrt{\theta_{p}^{2}+2 \theta_{p}}} .
\end{gathered}
$$

In formula (3) $\alpha_{p}$ is the angle of reference profile on the pitch line [25]

$$
\frac{\pi}{8 h}<\operatorname{tg} \alpha_{p}<\frac{\pi}{4 h}
$$

The range (5) determines the region of existence of hyperbolic transmission. Values of $h$ and $\alpha_{p}$ need to be the same as in the similar involute transmission.

Parameter $\theta_{p}$ in formula (4) is the value of $\theta$ on the pitch line. It determines from (2) when $\lambda=0$, i.e. $\theta_{p}=h / a$.

The profile angle of the hyperbolic reference profile at an arbitrary point is defined as

$$
\operatorname{tg} \alpha=y_{r}^{\prime}=\frac{b}{a} \cdot \frac{1+\theta}{\sqrt{\theta^{2}+2 \theta}} .
$$

The profile angle can also be determined by dependencies

$$
\begin{aligned}
& \sin \alpha=\frac{b(1+\theta)}{\sqrt{\left(a^{2}+b^{2}\right)(1+\theta)-a^{2}}} ; \\
& \cos \alpha=a \sqrt{\frac{\theta^{2}+2 \theta}{\left(a^{2}+b^{2}\right)(1+\theta)-a^{2}}} .
\end{aligned}
$$


Parameters of the hyperbolic reference profile are the basis of the following studies in which equations (1)-(7) will be used.

2. Generating surface and its elements. If we describe the machining process as meshing of a rack tool (generating surface) with machined gears, the surface of the tooth will be an enveloping of the generating surface. To obtain the equation of the generating surface, we define the coordinate system $S_{S}$ which is associated with the generating surface. So the equation of this surface in the $S_{s}$ coordinate system is

$$
x_{s}=\lambda ; \quad y_{s}=\frac{\pi}{4}-b \sqrt{\theta^{2}+2 \theta} ; \quad z_{s}=\mu
$$

where $\mu$ is the variable value (Fig. 2).

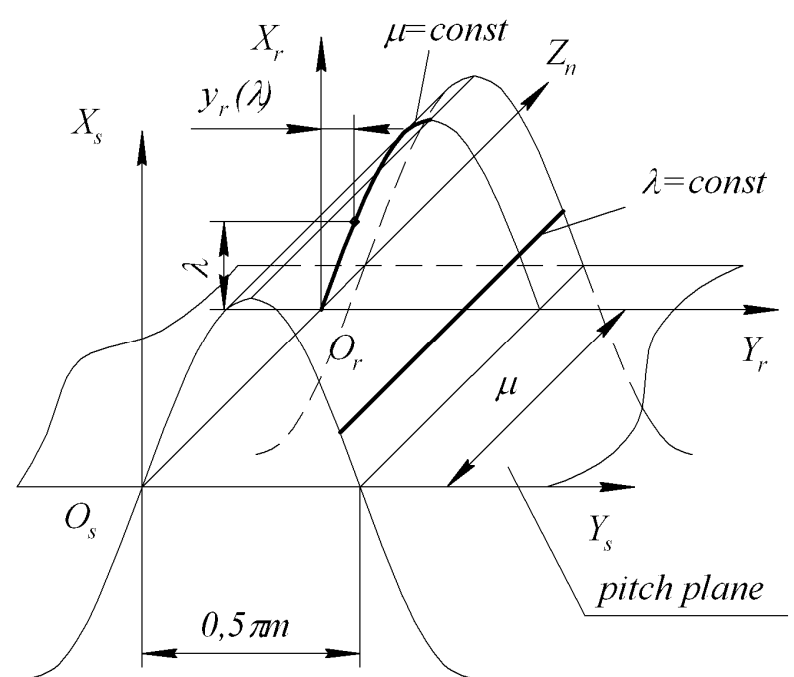

Fig. 2 - Basic parameters of generating surface

To obtain the formulas for determining the performance indicators of cylindrical gears, such elements of the generating surface as normal and its projections on the coordinate axis, the coefficients of the first and second quadratic forms, and the normal curvatures in the given directions are required.

The vector of normal is determined by [26]

$$
\mathbf{N}_{s}=\mathbf{r}_{s}^{\lambda} \times \mathbf{r}_{s}^{\mu},
$$

where $\mathbf{r}_{s}^{\lambda}$ and $\mathbf{r}_{s}^{\mu}$ is the partial derivatives of the radius-vector of the generating surface (6) by the variables $\lambda$ and $\mu$ :

$$
\begin{gathered}
x_{s}^{\lambda}=1 ; x_{n}^{\mu}=0 ; \\
y_{s}^{\lambda}=\frac{b}{a} \cdot \frac{1+\theta}{\sqrt{\theta^{2}+2 \theta}} ; y_{n}^{\mu}=0 ; \\
z_{s}^{\lambda}=0 ; \quad z_{s}^{\mu}=1 .
\end{gathered}
$$

Substituting (10) into (9), we obtain the projections of the normal vector to the generating surface

$$
N_{s x}=\frac{b}{a} \cdot \frac{1+\theta}{\sqrt{\theta^{2}+2 \theta}} ; \quad N_{s y}=1 ; \quad N_{s z}=0 .
$$

The module of the normal vector (11) is obtained taking into account [26]

$$
n=\frac{1}{a} \sqrt{\frac{\left(a^{2}+b^{2}\right)(1+\theta)-a^{2}}{\theta^{2}+2 \theta}} .
$$

Then the unitary normal vector is

$$
\begin{gathered}
e_{s x}=\frac{b(1+\theta)}{\sqrt{\left(a^{2}+b^{2}\right)(1+\theta)-a^{2}}} ; \\
e_{s y}=-a \sqrt{\frac{\theta^{2}+2 \theta}{\left(a^{2}+b^{2}\right)(1+\theta)-a^{2}}} ; e_{s z}=0 .
\end{gathered}
$$

The coefficients of the first quadratic form in the general case are equal [26]

$$
\begin{gathered}
E_{s}=\left(x_{s}^{\lambda}\right)^{2}+\left(y_{s}^{\lambda}\right)^{2}+\left(z_{s}^{\lambda}\right)^{2} ; F_{s}=x_{s}^{\lambda} x_{s}^{\mu}+y_{s}^{\lambda} y_{s}^{\mu}+z_{s}^{\lambda} z_{s}^{\mu} ; \\
G_{s}=\left(x_{s}^{\mu}\right)^{2}+\left(y_{s}^{\mu}\right)^{2}+\left(z_{s}^{\mu}\right)^{2} .
\end{gathered}
$$

For the surface (8), substituting (10) into (14) we get

$$
E_{s}=1+\frac{b^{2}}{a^{2}} \cdot \frac{(1+\theta)^{2}}{\theta^{2}+2 \theta} ; \quad F_{s}=0 ; \quad G_{s}=1
$$

The coefficients of the second quadratic form [8]

$$
\begin{aligned}
& L_{s}=x_{s}^{\lambda \lambda} e_{s x}+y_{s}^{\lambda \lambda} e_{s y}+z_{s}^{\lambda \lambda} e_{s z} ; \\
& M_{s}=x_{s}^{\lambda \mu} e_{s x}+y_{s}^{\lambda \mu} e_{s y}+y_{s}^{\lambda \mu} e_{s z} ; \\
& N_{s}=x_{s}^{\mu \mu} e_{s x}+y_{s}^{\mu \mu} e_{s y}+z_{s}^{\mu \mu} e_{s z} .
\end{aligned}
$$

The second derivatives of the radius-vector (8) of the generating surface with respect to a variable $\lambda$ and $\mu$ are

$$
\begin{gathered}
x_{s}^{\lambda \lambda}=0 ; \quad y_{s}^{\lambda \lambda}=\frac{b}{a^{2}\left(\theta^{2}+2 \theta\right)^{3 / 2}} ; \quad z_{s}^{\lambda \lambda}=0 ; \\
x_{s}^{\lambda \mu}=0 ; \quad y_{s}^{\lambda \mu}=0 ; \quad z_{s}^{\lambda \mu}=0 ; \\
x_{s}^{\mu \mu}=0 ; \quad y_{s}^{\mu \mu}=0 ; \quad z_{s}^{\mu \mu}=0 .
\end{gathered}
$$

Substituting (17) into (16), we obtain the coefficients of the second quadratic form

$$
\begin{gathered}
L_{s}=\frac{b}{a\left(\theta^{2}+2 \theta\right) \sqrt{\left(a^{2}+b^{2}\right)(1+\theta)-a^{2}}} \\
M_{s}=0 ; \quad N_{s}=0 .
\end{gathered}
$$

The coefficients (15) and (18) are the function of the parameters that determine the hyperbolic reference profile; formulas (15) and (18) are valid for spur racks with a hyperbolic profile.

The normal curvature of the production surface in general terms is determined by the formula [26]

$$
K=\frac{L_{n} d \lambda^{2}+2 M_{n} d \lambda d \mu+N_{n} d \mu^{2}}{E_{n} d \lambda^{2}+2 F_{n} d \lambda d \mu+G_{n} d \mu^{2}},
$$


where $d \lambda$ and $d \mu$ are the differentials of $\lambda$ and $\mu$ coordinate lines.

The direction in which the curvature is determined depends on $d \lambda$ and $d \mu$ values. Thus, for example, the curvature along the lines $\lambda=$ const (Fig. 2) is obtained when $d \lambda=0$ from (19) as

$$
K_{\mu}=\frac{N_{n}}{G_{n}}=0 .
$$

That is typical for spur gears.

The curvature along the $\mu=$ const lines is the curvature of the reference profile (Fig. 2), it is equal to

$$
K_{\lambda}=\frac{L_{n}}{E_{n}}=-\frac{a b}{\left[\left(a^{2}+b^{2}\right)(1+\theta)-a^{2}\right]^{3 / 2}} .
$$

Inasmuch as the coefficients of the quadratic forms $F_{s}=0$ and $M_{s}=0$ for the considered generating surface, then coordinate lines $\lambda=$ const and $\mu=$ const are the lines of curvature, and the normal curvatures (20) and (21) are the main curvatures of the surface (6). After substituting (2) into (21), reducing to the hyperbola coordinate system $X_{h} O_{h} Y_{h}$ (Fig. 1) and after corresponding transformations we get a well-known formula for determining the curvature of hyperbola

$$
K_{\lambda}=\frac{a b}{\left(r_{1} r_{2}\right)^{3 / 2}}
$$

where $r_{1} \mathrm{i} r_{2}$ - focal radii of the corresponding points on the reference profile.

3. Machining gearing. Let's consider the formation of the spur gears by rack-type tool. To study the machining gearing, i.e. the meshing of the rack-type tool with machined gears, we will define the following coordinate system (Fig. 3):

$S_{1}$ - coordinate system related to the pinion;

$S_{2}$ - coordinate system related to the gear;

$S$ - fixed coordinate system.

The pitch cylinder of the workpiece rolls along the pitch plane of the generating surface. The plane $Y_{s} O_{s} Z_{s}$ is the pitch plane of the rack; the plane $Y O Z$ coincides with the plane $Y_{s} O_{s} Z_{s}$, in addition, the origin $O$ coinciding with the pitch. The axis $O Y$ coincides with the axis $O_{s} Y_{s}$. The plane $Y O X$ passes through the middle butt section of the transmission. The axes $O_{1} Z_{1}$ and $O_{2} Z_{2}$ are parallel to axis $O Z$; it is the axes of rotation of pinion and gear respectively. The radii of the pitch cylinders symbolize by $R_{1}$ for the pinion and $R_{2}$ for the gear; $\varphi_{1}$ and $\varphi_{2}$ are the angles of rotation of the pinion and gear. In the following, the index "1" will denote the parameters related to the pinion, the index "2" - the parameters related to the gear. Hence we will accept $i=1$ for the pinion $i=2$ for the gear, and when the workpiece is rotated to the corner $\varphi_{i}$, the surface is moved to the distance $R_{i} \varphi_{i}$.

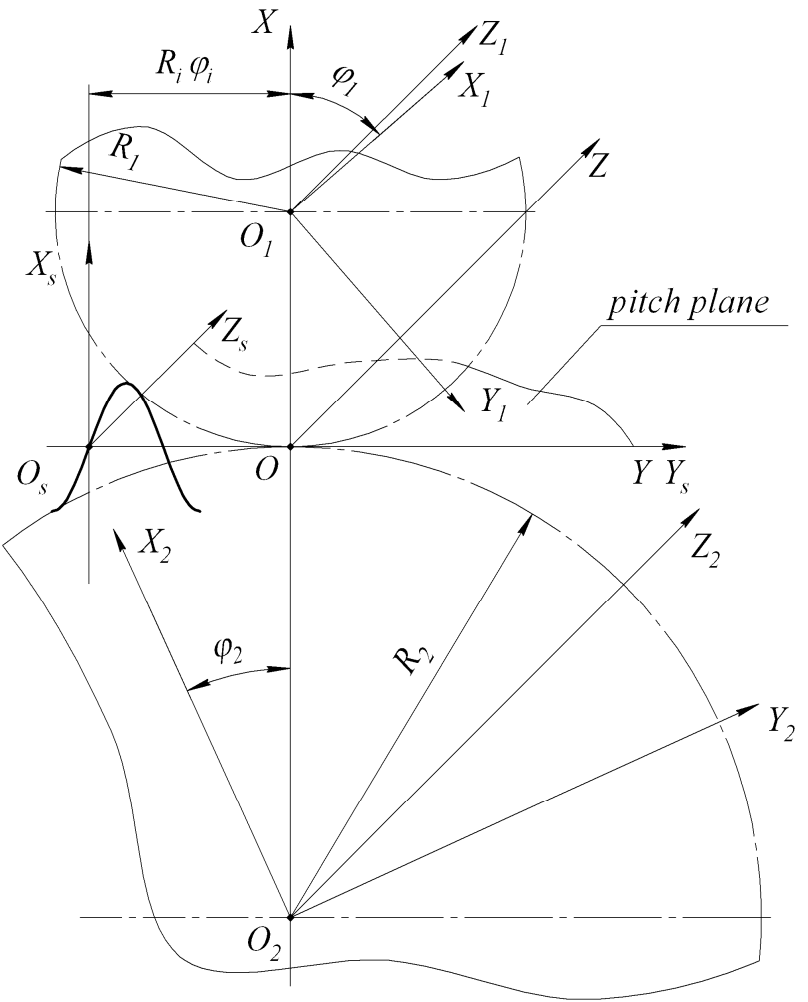

Fig. 3 - Coordinate systems

The transition from one coordinate system to another will be implemented in a matrix way. In the following we will need the matrices of the transition which are known from [27]. Applying the transition matrix from $S_{n}$ to $S$, we obtain in a fixed coordinate system the equation of generating surface

$$
x=\lambda=h-a \theta ; \quad y=\frac{\pi}{4}-b \sqrt{\theta^{2}+2 \theta}-R_{i} \varphi_{i} ; \quad z=\mu .
$$

The equation of the machining gearing of the generating surface with the cutting gear has the form [27]

$$
F_{i}=\mathbf{V}^{s i} \cdot \mathbf{e}_{s}=0
$$

where $\mathbf{V}^{s i}$ - the relative speed in the machining gearing of the generating surface with the machined gear [28], it is equal to

$$
\mathbf{V}^{s i}=\mathbf{M}_{s i} \frac{d \mathbf{M}_{i s}}{d \varphi_{i}} \mathbf{r}_{s}
$$

where $\mathbf{M}_{s i}$ - the transition matrix from $S_{i}$ to $S_{s}$

$$
\mathbf{M}_{s i}=\left\|\begin{array}{cccc}
\cos \varphi_{i} & \pm \sin \varphi_{i} & 0 & \mp R_{i} \\
\mp \sin \varphi_{i} & \cos \varphi_{i} & 0 & R_{i} \varphi_{i} \\
0 & 0 & 1 & 0 \\
0 & 0 & 0 & 1
\end{array}\right\|
$$

$\frac{d \mathbf{M}_{i s}}{d \varphi_{i}}-$ derivative by the parameter $\varphi$ of the matrix $\mathbf{M}_{\text {is }}$ which is reverse to (25), 


$$
\frac{d \mathbf{M}_{i s}}{d \varphi_{i}}=\left\|\begin{array}{cccc}
-\sin \varphi_{i} & \mp \cos \varphi_{i} & 0 & \pm R_{i} \varphi_{i} \cos \varphi_{i} \\
\pm \cos \varphi_{i} & -\sin \varphi_{i} & 0 & R_{i} \varphi_{i} \sin \varphi_{i} \\
0 & 0 & 1 & 0 \\
0 & 0 & 0 & 1
\end{array}\right\|
$$

$\mathbf{r}_{s}$ - the radius vector of the generating surface, its projection in a fixed coordinate system is (22).

Given (24), (25) and (26) we get

$$
\mathbf{V}^{s i}=\mp\left(\frac{\pi}{4}-b \sqrt{\theta^{2}+2 \theta}-R_{i} \varphi_{i}\right) \mathbf{i} \pm(h-a \theta) \mathbf{j} .
$$

where $\mathbf{i}$ and $\mathbf{j}$ are the unitary vectors of the Cartesian coordinate system.

To obtain the true value of the relative velocity, the right part of (27) should be multiplied by the angular velocity $\omega_{i}$.

Substituting the values (11) and (27) into (23) we obtain the equation of machining gearing

$$
F_{i}=\mp \frac{\left(\frac{\pi}{4}-b \sqrt{\theta^{2}+2 \theta}-R_{i} \varphi_{i}\right)+a(h-a \theta) \sqrt{\theta^{2}+2 \theta}}{\sqrt{\left(a^{2}+b^{2}\right)(1+\theta)-a^{2}}}=0 .
$$

Equation (28) defines the relation between the parameter $\theta$ (the height parameter $\lambda$ ) and the angle $\varphi$. Having solved equation (28) it is possible to determine $\varphi_{i}$ which corresponds to a certain position of the contact line on the generating surface

$$
\varphi_{i}=\frac{1}{R_{i}}\left[\frac{\pi}{4}-\left(b-\frac{a}{b} \cdot \frac{h-a \theta}{1+\theta}\right) \sqrt{\theta^{2}+2 \theta}\right] .
$$

When solving the inverse problem, from the relation (28) we have the equation of fourth order

$$
\theta^{4}+B_{\varphi} \theta^{3}+C_{\varphi} \theta^{2}+D_{\varphi} \theta+E_{\varphi}=0
$$

where

$$
\begin{gathered}
B_{\varphi}=\frac{b^{2}[4-2 a(h-3 a)]-2 a^{3}(h-a)}{b^{2}+2 a^{2} b^{2}+a^{4}} ; \\
C_{\varphi}=\frac{b^{2}\left[5-2 a(3 h-2 a)-\left(\frac{\pi}{4}-R_{i} \varphi_{i}\right)^{2}\right]+2 a^{2} h(h-4 a)}{b^{2}+2 a^{2} b^{2}+a^{4}} ; \\
D_{\varphi}=\frac{b^{2}\left[2-4 a h-2\left(\frac{\pi}{4}-R_{i} \varphi_{i}\right)^{2}\right]+2 a^{2} h^{2}}{b^{2}+2 a^{2} b^{2}+a^{4}} ; \\
\left.E_{\varphi}=-\frac{\pi}{4}-R_{i} \varphi_{i}\right)^{2} b^{2} \\
b^{2}+2 a^{2} b^{2}+a^{4}
\end{gathered}
$$

The real root of equation (30) will determine the point on the reference profile which is corresponding to $\varphi_{i}=$ const .

Equations (28) and (22) determine the surface of the machining gearing, i.e. the geometric locus of the points where the contact between the generating surface and the machined surface occurs. Excluding any parameter from these equations, for example $\varphi$, we obtain the equation of the surface of the machining gearing

$$
x=h-a \theta ; \quad y=-\frac{a}{b} \cdot \frac{(h-a \theta) \sqrt{\theta^{2}+2 \theta}}{1+\theta} ; z=\mu .
$$

When the same generating surfaces are used for cutting of the both of pinion and gear will have a case of line contact in the working gearing. For gears, which are cut without the addendum modification shift, as well as for Xgears with equal shift, the surface of the machining gearing coincides with the surface of action of the pinion and gear. Equation (31) defines the line of machining gearing at the butt plane ( $z=$ const). For gear pairs with a line contact, this line of machining gearing will be the line of action of the wheels in the butt plane. Bringing (31) to an explicit form when $z=$ const we have

$$
y=-\frac{a}{b} \cdot \frac{x \sqrt{(h-x)^{2}+2 a(h-x)}}{a+h-x},
$$

and after changing

$$
(a+h-x)^{2}\left(b^{2} y^{2}-a^{2} x^{2}\right)+a^{4} x^{2}=0 .
$$

Consequently, for hyperbolic gears the line of action is the curve of the forth order, which is similar to conchoid of Nicomedes.

Equations (22) and (28) determine the line of instantaneous contact of the generating surface and the surfaces of the teeth of the cutting gears. For gears, which are cut without the addendum modification shift, as well as for Xgears with equal shift, this line coincides with the instantaneous contact line of pinion and gear teeth.

Taking into account (27) and (28) relative speed in machining gearing is determined by the formula

$$
\bar{V}^{n i}=\mp \frac{a}{b} \cdot \frac{(h-a \theta) \sqrt{\theta^{2}+2 \theta}}{1+\theta} \mathbf{i} \pm(h-a \theta) \mathbf{j} .
$$

The upper sign and $i=1$ is taken for the teeth of the pinion, the bottom one and $i=2$ is taken for the teeth of the gear in equations (25) - (28) and (32).

4. Parameters of the teeth surfaces of the machined gears. To determine the equations of the teeth surfaces of the hyperbolic pinion and gear, it is necessary to represent the equation of the surface of machining gearing in coordinate systems $S_{1}$ or $S_{2}$. To do this, we use the matrix of the transition from $S$ to $S_{i}$ [27]

$$
\mathbf{M}_{i 0}=\left\|\begin{array}{cccc}
\cos \varphi_{i} & \mp \sin \varphi_{i} & 0 & \pm R_{i} \cos \varphi_{i} \\
\pm \sin \varphi_{i} & \cos \varphi_{i} & 0 & R_{i} \sin \varphi_{i} \\
0 & 0 & 1 & 0 \\
0 & 0 & 0 & 1
\end{array}\right\| .
$$

The equation of the teeth surfaces of the pinion $(i=1)$ and the gear $(i=2)$ in the coordinate system $S_{i}$ is given by 


$$
\begin{gathered}
x_{i}=\left(h-a \theta \pm R_{i}\right) \cos \varphi_{i} \pm \frac{a}{b} \cdot \frac{(h-a \theta) \sqrt{\theta^{2}+2 \theta}}{1+\theta} \sin \varphi_{i} \\
y_{i}= \pm\left(h-a \theta \pm R_{i}\right) \sin \varphi_{i}+\frac{a}{b} \cdot \frac{(h-a \theta) \sqrt{\theta^{2}+2 \theta}}{1+\theta} \cos \varphi_{i} \\
z_{i}=\mu .
\end{gathered}
$$

The equations (33) allow us to determine the thickness of the root part of the teeth at the bending stress calculation, as well as the control dimensions of the gears which are cut. The equation (33) is the equation of the instantaneous contact lines of the gears when $\varphi_{i}=$ const . These equations describe the teeth profile of the pinion and gear at the butt section when $z=$ const .

The equation (33) determines the ruling of cylinders when $\lambda=$ const . The radii of these cylinders can be determined by the formula

$$
R_{b i}=\sqrt{x_{i}^{2}+y_{i}^{2}}
$$

or taking into account (33)

$$
R_{b i}=\sqrt{\left(h-a \theta \pm R_{i}\right)^{2}+\frac{a^{2}}{b^{2}} \cdot \frac{(h-a \theta)^{2}\left(\theta^{2}+2 \theta\right)}{(1+\theta)^{2}}}
$$

The equation (34) can be used to determine the value of $\lambda_{i}{ }^{*}$ which correspond to the boundary points of the contact zone. To do this, in the left part of the relation (34) we will substitute the values of $R_{a 1}$ and $R_{a 2}$ which are the outside radii of the pinion and the gear. We have an equation of fourth degree

$$
\theta^{4}+B_{a} \theta^{3}+C_{a} \theta^{2}+D_{a} \theta+E_{a}=0
$$

where

$$
\begin{gathered}
B_{a}=2 \cdot \frac{a^{2}(a-h)-b^{2}\left(h \pm R_{i}-a\right)}{a b^{2}+a^{3}} ; \\
C_{a}=\frac{b^{2}\left\lfloor a^{2}-4 a\left(h \pm R_{i}\right)-\left(h \pm R_{i}\right)^{2}-R_{a i}^{2}\right\rfloor+a^{2} h(h-4 a)}{a^{2} b^{2}+a^{4}} ; \\
D_{a}=2 \cdot \frac{b^{2}\left(h \pm R_{i}\right)\left(h \pm R_{i}-a\right)+a^{2} h^{2}-R_{a i}^{2} b^{2}}{a^{2} b^{2}+a^{4}} ; \\
E_{a}=-\frac{b^{2}\left\lfloor\left(h \pm R_{i}\right)^{2}-R_{a i}^{2}\right\rfloor}{a^{2} b^{2}+a^{4}} .
\end{gathered}
$$

The real root of equation (35) will determine the value of the parameter $\theta_{i}^{*}$ which are correspond to $\lambda_{i}{ }^{*}$. Obtained $\lambda_{i} *$ should be used to determining the performance indicators of working gearing.

To determine the thickness of the teeth at the butt section, it is necessary to determine $\lambda_{i} *$ from the equation (34) for the given $R_{b 1}$ and $R_{b 2}$, and the angle $\varphi_{i}{ }^{*}$ from the equation of gearing (28). Substituting the obtained $\lambda_{i}^{*}$ and $\varphi_{i}^{*}$ into equation (33) we find the coordinates of the profile of the tooth at the butt section which are correspond to $R_{b 1}$ and $R_{b 2}$. For a symmetrical reference profile, the tooth thickness of the pinion and the gear at the butt section is equal to

$$
\begin{aligned}
S= & \frac{\pi}{2}-2\left|y_{i}\right|=\frac{\pi}{2}-2 \mid \pm\left(h-a \theta_{i}^{*} \pm R_{i}\right) \sin \varphi_{i}^{*}- \\
& -\frac{a}{b} \cdot \frac{\left(h-a \theta_{i}^{*}\right) \sqrt{\left(\theta_{i}^{*}\right)^{2}+2 \theta_{i}^{*}}}{1+\theta_{i}^{*}} \cos \varphi_{i}^{*} \mid .
\end{aligned}
$$

The distance from the tip of the tooth to the measuring chord (measuring height) is equal to

$$
h^{*}=R_{a i}-x_{i}^{*},
$$

The coordinates $x_{i}$ in (37) are determined from the equations (33) with $\lambda_{i} *$ and $\varphi_{i}^{*}$.

To prevent the pointing of the teeth at the design stage, the thickness of the teeth tips is need to be determined. To do it the relation (36) could be use, but it is necessary to take the outside radii $R_{a i}$ instead the $R_{b i}$ when determining $\lambda_{i}{ }^{*}$ and $\varphi_{i}{ }^{*}$.

5. Coefficients of quadratic forms of teeth surfaces. The first and second quadratic forms are the important geometric characteristic of the teeth surfaces, the coefficients of quadratic forms we define by formulas [26]

$$
\begin{gathered}
E_{i}=\left(x_{i}^{\lambda}\right)^{2}+\left(y_{i}^{\lambda}\right)^{2}+\left(z_{i}^{\lambda}\right)^{2} ; F_{i}=x_{i}^{\lambda} x_{i}^{\varphi}+y_{i}^{\lambda} y_{i}^{\varphi}+z_{i}^{\lambda} z_{i}^{\varphi} ; \\
G_{i}=\left(x_{i}^{\varphi}\right)^{2}+\left(y_{i}^{\varphi}\right)^{2}+\left(z_{i}^{\varphi}\right)^{2} ; \\
L_{i}=-x_{i}^{\lambda} e_{x i}^{\lambda}-y_{i}^{\lambda} e_{y i}^{\lambda}-z_{i}^{\lambda} e_{z i}^{\lambda} ; M_{i}=-x_{i}^{\varphi} e_{x i}^{\lambda}-y_{i}^{\varphi} e_{y i}^{\lambda}-z_{i}^{\varphi} e_{z i}^{\lambda} ; \\
N_{i}=-x_{i}^{\varphi} e_{x i}^{\varphi}-y_{i}^{\varphi} e_{y i}^{\varphi}-z_{i}^{\varphi} e_{z i}^{\varphi},
\end{gathered}
$$

where $x_{i}^{\lambda}, y_{i}^{\lambda}, z_{i}^{\lambda}, x_{i}^{\varphi}, y_{i}^{\varphi}, z_{i}^{\varphi}-$ derivatives of the radius vector (33) by $\lambda$ and $\varphi$ respectively;

$$
e_{x i}^{\lambda}, e_{y i}^{\lambda}, e_{z i}^{\lambda}, e_{x i}^{\varphi}, e_{y i}^{\varphi}, e_{z i}^{\varphi}-\text { derivatives of projections of }
$$
the unit normal vector to the teeth surfaces by $\lambda$ and $\varphi$ respectively.

Derivatives of the radius vector (33) are equal

$$
\begin{gathered}
x_{i}^{\lambda}=\cos \varphi_{i} \pm \frac{a(1+\theta)^{3}-(a+h)}{b(1+\theta)^{2} \sqrt{\theta^{2}+2 \theta}} \sin \varphi_{i} ; \\
y_{i}^{\lambda}= \pm \sin \varphi_{i}+\frac{a(1+\theta)^{3}-(a+h)}{b(1+\theta)^{2} \sqrt{\theta^{2}+2 \theta}} \cos \varphi_{i} ; z_{i}^{\lambda}=0 ; \\
x_{i}^{\varphi}=-\left(h-a \theta \pm R_{i}\right) \sin \varphi_{i} \pm \frac{a}{b} \cdot \frac{(h-a \theta) \sqrt{\theta^{2}+2 \theta}}{1+\theta} \cos \varphi_{i} ; \\
y_{i}^{\varphi}= \pm\left(h-a \theta \pm R_{i}\right) \cos \varphi_{i}-\frac{a}{b} \cdot \frac{(h-a \theta) \sqrt{\theta^{2}+2 \theta}}{1+\theta} \sin \varphi_{i} ; \\
z_{i}^{\varphi}=0 .
\end{gathered}
$$

Normal unit vector of the teeth surfaces (33) of the pinion and gear related with the normal unit vector of generating surface (6) by formulas 


$$
\begin{gathered}
e_{i x}^{\lambda}=e_{s x}^{\lambda} \cos \varphi_{i} \mp e_{s y}^{\lambda} \sin \varphi_{i} ; \\
e_{i y}^{\lambda}= \pm e_{s x}^{\lambda} \sin \varphi_{i}+e_{s y}^{\lambda} \cos \varphi_{i} ; \quad e_{i z}^{\lambda}=e_{s z}^{\lambda} ; \\
e_{i x}^{\varphi}=e_{s x}^{\varphi} \cos \varphi_{i}-e_{s x} \sin \varphi_{i}+e_{s y}^{\varphi} \sin \varphi_{i} \mp e_{s y} \cos \varphi_{i} ; \\
e_{i y}^{\varphi}= \pm\left(e_{s x}^{\varphi} \sin \varphi_{i}+e_{s x} \cos \varphi_{i}\right)+e_{s y}^{\varphi} \cos \varphi_{i}+e_{s y} \sin \varphi_{i} ; \\
e_{i z}^{\phi}=e_{s z}^{\phi} .
\end{gathered}
$$

Derivatives of projections of the normal unit vector of the teeth surfaces can be determined by derivatives of the normal unit vector (13) of the generating surface (6), which are equal to

$$
\begin{gathered}
e_{s x}^{\lambda}=\frac{a b}{\left[\left(a^{2}+b^{2}\right)(1+\theta)-a^{2}\right]^{3 / 2}} ; \\
e_{s y}^{\lambda}=\frac{b^{2}(1+\theta)}{\left[\left(a^{2}+b^{2}\right)(1+\theta)-a^{2}\right]^{3 / 2} \sqrt{\theta^{2}+2 \theta}} ; \\
e_{s z}^{\lambda}=0 ; \\
e_{s x}^{\varphi}=0 ; \quad e_{s y}^{\varphi}=0 ; \quad e_{s z}^{\varphi}=0 .
\end{gathered}
$$

Substituting (44) and (45) into (42) and (43) respectively, we obtain the necessary derivatives of orts

$$
\begin{gathered}
e_{x i}^{\lambda}=\frac{a b \sqrt{\theta^{2}+2 \theta} \cos \varphi_{i} \mp b^{2}(1+\theta) \sin \varphi_{i}}{\left[\left(a^{2}+b^{2}\right)(1+\theta)-a^{2}\right]^{3 / 2} \sqrt{\theta^{2}+2 \theta}} ; \\
e_{y i}^{\lambda}=\frac{ \pm a b \sqrt{\theta^{2}+2 \theta} \sin \varphi_{i}+b^{2}(1+\theta) \cos \varphi_{i}}{\left[\left(a^{2}+b^{2}\right)(1+\theta)-a^{2}\right]^{3 / 2} \sqrt{\theta^{2}+2 \theta}} ; \\
e_{z i}^{\lambda}=0 ; \\
e_{y i}^{\varphi}=\frac{ \pm b(1+\theta) \sin \varphi_{i} \pm a \sqrt{\theta^{2}+2 \theta} \cos \varphi_{i}}{\sqrt{\left(a^{2}+b^{2}\right)(1+\theta)-a^{2}}} ; \\
\sqrt{\left(a^{2}+b^{2}\right)(1+\theta)-a^{2}} \\
e_{z i}^{\varphi}=0 .
\end{gathered}
$$

After the corresponding substitution (40), (41) and (46), (47) into (38) and (39) for the teeth surfaces of the pinion and gear we obtain:

- the coefficients of the first quadratic forms

$$
\begin{gathered}
E_{i}=1+\frac{a^{2}\left[(1+\theta)^{3}-(a+h)\right]}{b^{2}(1+\theta)^{4}\left(\theta^{2}+2 \theta\right) ;} \\
F_{i}= \pm \frac{a(h-a \theta)}{b} \cdot \frac{a(1+\theta)^{3}-(a+h)-b(1+\theta)\left(\theta^{2}+2 \theta\right)}{b(1+\theta)^{2} \sqrt{\theta^{2}+2 \theta}} ; \\
G_{i}=\frac{(h-a \theta)^{2}\left[\left(a^{2}+b^{2}\right)(1+\theta)-a^{2}\right]}{b^{2}(1+\theta)^{2}} ;
\end{gathered}
$$

- the coefficients of the second quadratic forms

$$
\begin{gathered}
L_{i}=-\frac{b(h-a \theta)}{(1+\theta)\left(\theta^{2}+2 \theta\right)\left[\left(a^{2}+b^{2}\right)(1+\theta)-a^{2}\right]^{3 / 2}} ; \\
M_{i}= \pm \frac{h-a \theta}{\left.(1+\theta) \sqrt{\left(\theta^{2}+2 \theta\right)\left[\left(a^{2}+b^{2}\right)(1+\theta)-a^{2}\right.}\right]}
\end{gathered}
$$

\section{Conclusions:}

1. The fundamentals of the mathematical model of spur gears with teeth which are formed by a hyperbolic basic rack are developed. For such transmission, the generating surface is mathematically described with the definition of its basic geometric characteristics; the gearing of this surface with the machined teeth is investigated; the equation of these teeth surfaces is obtained, as well as the basic geometrical characteristics of these surfaces. The obtained equations also allow to determine the boundaries of the contact zone, the control dimensions of the teeth and to set limitations at the design stage.

2. Using the results obtained in the article, in the following it is possible to determine all geometric characteristics of the surfaces of the pinion and gears (for example, the curvature of the teeth surfaces in any given direction etc.). These characteristics are the basis for determining the performance indicators of transmission, whose teeth are generating by a hyperbolic basic rack. The comparative analysis of such transmissions can be carried out not only with traditional, but also with other types of gearings with the use of these indicators.

\section{References}

1. Гольдфарб В.И. Некоторые аспекты современного состояния теории и практики зубчатых передач. Сборник докладов научнотехнической конференции "Теория и практика зубчатых передач и редукторосроения". Ижевск, 2008. С. 8-15.

2. World Gears - Demand and Sales Forecasts, Market Share, Market Size, Market Leaders. Report by The Freedonia Group, Inc. URL: https://www.freedoniagroup.com/World-Gears.html

3. 2018 State of the Gear Industry Reader. Survey Results. Gear Technology. January/February 2018. pp. 30-36. URL: https://www.geartechnology.com/articles/0118/2018_State_of_the_ Gear Industry/

4. Вулгаков Э.Б. Общий случай синтеза эвольвентного зацепления. Труды Рижского института инженеров гражданской авиачии. Сб: "Исследование механических передач приводов агрегатов". 1970. Вып. 148. С. 55-68.

5. Вулгаков Э.Б. Зубчатые передачи с улучшенными свойствами. Обобщенная теория и проектирование. Москва: Машиностроение, 1974. 264 c.

6. Бабичев Д.Т., Смовж А.И., Кривошея А.В. Синтез современных цилиндрических прямозубых эвольвентных передач в курсе "Прикладная механика". Збірник наукових праць "Вісник НТУ "ХПІ". Серія: Проблеми механічного приводу. Харків, НТУ "ХПІ", 2015. №35. С. 10-19.

7. Amani A., Spitas C., Spitas V. Generalised non-dimensional multiparametric involute spur gear design model considering manufacturability and geometrical compatibility. Mechanism and Machine Theory, 2017. № 109. pp. 250-277.

8. Павлов А.И. Современная теория зубчатых зацеплений. Монография. Харьков: ХНАДУ, 2005. 100 с.

9. Протасов Р.В., Устиненко А.В. Исследование области рационального существования эволютного зацепления. Збірник на- 
укових праць "Вісник НТУ "ХПІ". Серія: Проблеми механічного приводу. Харків, НТУ "ХПІ", 2013. №41. С. 124-128.

10. Попов А.П. Нагрузочная способность энкаитных зубчатых передач по контактным напряжениям. Збірник наукових праць "Вісник НТУ "ХПI". Серія: Проблеми механічного приводу. Харків, НТУ "ХПІ", 2004. №30. С. 61-68.

11. Tököly P., Gajdoš M. , Bošanský M. Effect of tooth shape to size of contact stress noninvolute gearing. Збірник наукових праць "Вісник НТУ "ХПІ". Серія: Проблеми механічного приводу. Харків: НТУ "ХПІ", 2009. №19. С. 10-20.

12. Kopiláková B., Bošanský M., Petrák L. Comparison of HRC and $\mathrm{C}-\mathrm{C}$ gearing for damage to pitting. Збірник наукових працьь "Bicник НТУ "ХПI". Серія: Проблеми механічного приводу. Харків, НТУ "ХПІ", 2016. №23. С. 77-81.

13. Шишов В.П., Носко П.Л., Филь П.В. Теоретические основы синтеза передач зачеплением. Луганськ: Вид-во СНУ ім. В Даля, 2006. 408 с

14. Ревякіна О.А. Удосконалювання ииліндричних передач із арковими зубиями синтезом за критеріями працездатності: Автореф. дис. ... канд. техн. наук. 05.02.02. Луганськ, 2003. 25 с.

15. Шишов В.П., Носко П.Л., Ткач П.М., Філь П.В. Високонаван тажені ииліндричні передачі з двоопукло-ввігнутими зубиями Монографія. Луганськ: вид-во СНУ ім. В. Даля, 2005. 216 с.

16. Шабанов И. Р. О зубчатой передаче с конхоидальной линией зацепления. Надежность и качество зубчатых передач. Нииинформтяжмаш, 1967. 18-67-106. С. 1-8.

17. Скляр Ю.А. Геометрокинематические критерии прямозубых конхоидальных передач со смещением исходного контура. 3бiрник наукових праць "Вісник НТУ "ХПI". Серія: Проблеми механічного приводу. Харків: НТУ "ХПІ", 2014. №31. С. 115-120.

18. Муховатый А.А. Неэвольвентные цилиндрические зубчатые передачи с улучшенными показателями нагрузочной способности. Збірник наукових прачь "Вісник НТУ "ХПI". Серія: Проблеми механічного приводу. Харків: НТУ "ХПІ", 2010. №27. С. 162-166.

19. Данильченко Ю.М., Пастернак С.І., Кривошея А.В. Продуктивність контурної обробки зубчастих ланок дисковим інструментом/ Вісник Національного технічного університету України "Київський політехнічний інститут". Серія: Машинобудування. 2008. №53. С. 215-225.

20. Пастернак С.І., Данильченко Ю.М. Сторчак М.Г., Кривошея А.В Економічне обгрунтування методу контурної обробки деталей періодичними профілями дисковим інструментом. Збірник наукових праиь "Вісник НТУ "ХПI". Серія: Проблеми механічного приводу. Харків: НТУ "ХПІ". 2009, №19. С. 118-126.

21. Грицай I.Є., Вільшанецький В.I. Удосконалення технології виготовлення зубчастих коліс на основі нового методу зубонарізання. Збірник наукових праць "Вісник НТУ "ХПІ". Серія: Проблеми механічного приводу. Харків: НТУ "ХПІ", 2011. №28. С. 44-52.

22. Бабичев Д.Т., Бабичев Д.А. Оптимизационный синтез профиля зуба как отрезка кривой, заданной натуральным уравнением. Теория и практика зубчатых передач: Сборник трудов Между народного симпозиума (21-23 января, 2014 г., Россия, Ижевск). Ижевск: изд-во ИжГТУ, 2013. С. 301-308.

23. Ткач П.М., Носко П.Л., Філь П.В., Ревякіна О.О. Якісні показники працездатності синусоїдальних циліндричних прямозубих передач. Збірник наукових праць "Вісник НТУ "ХПI". Серія Проблеми механічного приводу. Харків: НТУ "ХПІ", 2017. №25(1247). С.135-139.

24. Ткач П.М. Виробна поверхня та верстатне зачеплення циліндричних прямозубих синусоїдальних передач. Вісник НТУУ "КПI". Серія: Машинобудування. Київ: НТУУ "КПІ", 2014. № 1(70). С. 112-121.

25. Ткач П.М. Визначення можливості профілювання вихідних контурів циліндричних прямозубих передач кривими другого порядку. Збірник наукових праць "Вісник НТУ "ХПI". Серія: Проблеми механічного приводу. Харків: НТУ "ХПІ", 2015. № 34 C. $135-144$.

26. Погорелов А.В. Дифференцииальная геометрия. Москва: Наука 1974. $176 \mathrm{c}$

27. Литвин Ф.Л. Теория зубчатых зацееллений. Москва: Наука, 1968. $584 \mathrm{c}$.

28. Дусев И.И. Связь между геометрическими и кинематическими параметрами высшей кинематической пары. Изв. Северо-Кавказского научного иентра высшей школь. 1973. № 3. С. 28-32.

\section{References (transliterated)}

1. Goljdfarb V.I. Nekotorihe aspektih sovremennogo sostoyaniya teori i praktiki zubchatihkh peredach. [Some aspects of the current state of the theory and practice of gears] Sbornik dokladov nauchnotekhnicheskoyj konferencii "Teoriya i praktika zubchatihkh peredach i reduktorosroeniya" [Proc. of the Scientific-technical Conf. "Theory and Practice of Gears and Reducer building] Izhevsk, 2008, pp. 8-15.

2. World Gears - Demand and Sales Forecasts, Market Share, Market Size, Market Leaders. Report by The Freedonia Group, Inc. URL: https://www.freedoniagroup.com/World-Gears.html

3. 22018 State of the Gear Industry Reader. Survey Results. Gear Technology. January/February 2018. pp. 30-36. URL: https://www.geartechnology.com/articles/0118/2018_State_of_the_ Gear_Industry/

4. Vulgakov Eh.B. Obthiyj sluchayj sinteza ehvoljventnogo zacepleniya [The general case of the synthesis of involute gearing]. Trudih Rizhskogo instituta inzhenerov grazhdanskoyj aviacii. Sb.: "Issledovanie mekhanicheskikh peredach privodov agregatov" [The Papers of the Riga Institute of Civil Aviation Engineers. Coll. "The study of the mechanical transmissions of drive units"]. 1970, vol. 148 , pp. 55-68.

5. Vulgakov Eh.B. Zubchatihe peredachi s uluchshennihmi svoyjstvami. Obobthennaya teoriya i proektirovanie [Gears with improved properties. Generalized theory and design]. Moscow, Mashinostroenie Publ., 1974, 264 p.

6. Babichev D.T., Smovzh A.I., Krivosheja A.V. Sintez sovremennyh cilindricheskih prjamozubyh jevol'ventnyh peredach v kurse "Prikladnaja mehanika" [Synthesis of modern cylindrical spur-gear involute transmissions in the course "Applied Mechanics"]. Zbirnyk naukovykh prats "Visnyk NTU "KhPI". Seriia: Problemy mekhanichnoho pryvodu [Collection of scientific papers "Bulletin of NTU "KhPI". Series: Problems of Mechanical Drive]. Kharkiv, NTU "KhPI" Publ., 2015, no. 35, pp. 10-19.

7. Amani A., Spitas C., Spitas V. Generalised non-dimensional multiparametric involute spur gear design model considering manufacturability and geometrical compatibility. Mechanism and Machine Theory, 2017, no. 109, pp. 250-277.

8. Pavlov A.I. Sovremennaya teoriya zubchatihkh zacepleniyj. Monografiya [The modern theory of gearing. Monography]. Kharjkov, KhNADU Publ., 2005, 100 p.

9. Protasov R.V., Ustinenko A.V. Issledovanie oblasti racional'nogo sushhestvovanija jevoljutnogo zaceplenija [Investigation of the region of the rational existence of an evolute gearing]. Zbirnyk naukovykh prats "Visnyk NTU "KhPI". Seriia: Problemy mekhanichnoho pryvodu [Collection of scientific papers "Bulletin of NTU "KhPI". Series: Problems of Mechanical Drive]. Kharkiv, NTU "KhPI" Publ., 2013, no. 41, pp. 124-128.

10. Popov A.P. Nagruzochnaja sposobnost' jenkaitnyh zubchatyh peredach po kontaktnym naprjazhenijam [Load capacity of enkaitic gears on contact stresses]. Zbirnyk naukovykh prats "Visnyk NTU "KhPI". Seriia: Problemy mekhanichnoho pryvodu [Collection of scientific papers "Bulletin of NTU "KhPI". Series: Problems of Mechanical Drive] Kharkiv, NTU "KhPI" Publ., 2004, no. 30, pp. 61-68.

11. Tököly P., Gajdoš M. , Bošanský M. Effect of tooth shape to size of contact stress noninvolute gearing. Zbirnyk naukovykh prats "Visnyk NTU "KhPI". Seriia: Problemy mekhanichnoho pryvodu [Collection of scientific papers "Bulletin of NTU "KhPI". Series: Problems of Mechanical Drive]. Kharkiv, NTU "KhPI" Publ., 2009, no. 19, pp. 10-20.

12. Kopiláková B., Bošanský M., Petrák L. Comparison of HRC and $\mathrm{C}-\mathrm{C}$ gearing for damage to pitting. Zbirnyk naukovykh prats "Visnyk NTU "KhPI". Seriia: Problemy mekhanichnoho pryvodu [Collection of scientific papers "Bulletin of NTU "KhPI". Series: Problems of Mechanical Drive]. Kharkiv, NTU "KhPI" Publ., 2016, no. 23, pp. 77-81.

13. V.P. Shishov, P.L. Nosko, P.V. Fil'. Teoreticheskie osnovih sinteza peredach zacepleniem [Theoretical basis for the synthesis of gearings]. Lugansjk, SNU im. V. Dalya Publ., 2006, 408 p.

14. Revyakina O.A. Udoskonalyuvannya tsylindrychnykh peredach iz arkovymy zubtsyamy syntezom za kryteriyamy pratsezdatnosti: Avtoref. dys. ... kand. tekhn. nauk [Improvement of cylindrical gear with arched teeth by synthesis according to the criteria of efficiency: the synopsis of PhD thesis]. Luhans'k, 2003, 25 p. 
15. Shyshov V.P., Nosko P.L., Tkach P.M., Fil P.V. Vysokonavantazheni tsylindrychni peredachi $z$ dvoopuklo-vvihnutymy zubtsiamy: Monohrafiia [Heavy-duty cylindrical transmissions with biconvexconcave teeth: Monograph]. Luhansk, SNU im. V. Dalia Publ., 2005, 216 p.

16. Shabanov I. R. O zubchatoj peredache s konhoidal'noj liniej zaceplenija [On gearing with a conchoidal line of action]. Nadezhnost' kachestvo zubchatyh peredach [Reliability and quality of the gears]. Niiinformtjazhmash Publ., 1967, no. 18-67-106, pp. 1-8.

17. Skljar Ju.A. Geometrokinematicheskie kriterii prjamozubyh konhoidal'nyh peredach so smeshheniem ishodnogo kontura [Geometric-kinematic criteria for spur gears with shift of the basic rack] Zbirnyk naukovykh prats "Visnyk NTU "KhPI". Seriia: Problemy mekhanichnoho pryvodu [Collection of scientific papers "Bulletin of NTU "KhPI". Series: Problems of Mechanical Drive]. Kharkiv, NTU "KhPI" Publ., 2014, no. 31, pp. 115-120.

18. Muhovatyj A.A. Nejevol'ventnye cilindricheskie zubchate peredachi s uluchshennymi pokazateljami nagruzochnoj sposobnosti [Noninvolute cylindrical gears with improved load capacity]. Zbirnyk naukovykh prats "Visnyk NTU "KhPI". Seriia: Problemy mekhanichnoho pryvodu [Collection of scientific papers "Bulletin of NTU "KhPI". Series: Problems of Mechanical Drive]. Kharkiv, NTU "KhPI" Publ., 2010, no. 27, pp. 162-166.

19. Danylchenko Yu.M., Pasternak S.I., Kryvosheya A.V. Produktyvnist konturnoi obrobky zubchastykh lanok dyskovym instrumentom [Performance of contour processing of gear units by disc-wim tool]. Visnyk Natsionalnoho tekhnichnoho universytetu Ukrainy "Kyivskyi politekhnichnyi instytut". Seriia: Mashynobuduvannia [Bulletin of the National Technical University of Ukraine "KPI". Series: Engineering]. 2008, no. 53, pp. 215-25.

20. Pasternak S.I., Danylchenko Yu.M., Storchack M.G., Kryvosheya A.V. Ekonomichne obgruntuvannia metodu konturnoi obrobky detalei $\mathrm{z}$ periodychnymy profiliamy dyskovym instrumentom [Economic substantiation of the method of contour processing of details with periodic profiles by a disk tool]. Zbirnyk naukovykh prats "Visnyk NTU "KhPI". Seriia: Problemy mekhanichnoho pryvodu [Collection of scientific papers "Bulletin of NTU "KhPI". Series: Problems of Mechanical Drive]. Kharkiv, NTU "KhPI" Publ., 2009, no. 19, pp. 118-126.

21. Gricayj I.E., Viljshanecjkiyj V.I. Udoskonalennya tekhnologiji vigotovlennya zubchastikh kolis na osnovi novogo metodu zubonarizannya [Improving of the technology of gear manufacturing on the basis of a new method of tooth cutting]. Zbirnyk naukovykh prats "Visnyk NTU "KhPI". Seriia: Problemy mekhanichnoho pryv- odu [Collection of scientific papers "Bulletin of NTU "KhPI". Series: Problems of Mechanical Drive]. Kharkiv, NTU "KhPI" Publ., 2011, no. 28, pp. 44-52.

22. Babichev D.T. Babichev D.A. Optimizacionnihyj sintez profilya zuba kak otrezka krivoyj, zadannoyj naturaljnihm uravneniem [Optimization synthesis of the tooth profile as a segment of the curve given by the natural equation]. Teoriya $i$ praktika zubchatihkh peredach: Sbornik trudov Mezhdunarodnogo simpoziuma (21-23 yanvarya, 2014 g., Rossiya, Izhevsk) [Theory and Practice of Gears: Proceedings of the International Symposium (January 21-23, 2014, Russia, Izhevsk)]. Izhevsk, IzhGTU Publ., 2013, pp. $301-308$.

23. Tkach P.M., Nosko P.L., Fil P.V., Reviakina O.O. Yakisni pokaznyky pratsezdatnosti synusoidalnykh tsylindrychnykh priamozubykh peredach [Qualitative performance indicators of sinusoidal cylindrical spur gears]. Zbirnyk naukovykh prats "Visnyk NTU "KhPI". Seriia: Problemy mekhanichnoho pryvodu [Collection of scientific papers "Bulletin of NTU "KhPI". Series: Problems of Mechanical Drive]. Kharkiv, NTU "KhPI" Publ., 2017, no. 25, pp. 135-139.

24. Tkach P.M. Vyrobna poverkhnya ta verstatne zacheplennya tsylindrychnykh pryamozubykh synusoyidal'nykh peredach [Producing surface and producing gearing of cylindrical spur sine transmissions]. Visnyk NTUU "KPI". Seriya: Mashynobuduvannya [Bulletin of the National Technical University of Ukraine "KPI". Series: Engineering]. Kyiv, NTUU "KPI" Publ., 2014, no. 1(70), pp. 112-121.

25. Tkach P.M. Vyznachennia mozhlyvosti profiliuvannia vykhidnykh konturiv tsylindrychnykh priamozubykh peredach kryvymy druhoho poriadku [Determination of the ability to outline the basic rack for spur gears by the second order curves]. Zbirnyk naukovykh prats "Visnyk NTU "KhPI". Seriia: Problemy mekhanichnoho pryvodu [Collection of scientific papers "Bulletin of NTU "KhPI". Series: Problems of Mechanical Drive]. Kharkiv, NTU "KhPI" Publ., 2015, no. 34, pp. 135-144.

26. Pogorelov A.V. Differencialjnaya geometriya [Differential geometry]. Moscow, Nauka Publ., 1974, 176 p.

27. Litvin F.L. Teoriya zubchatihkh zacepleniyj [Theory of gearing]. Moscow, Nauka Publ., 1968, 584 p.

28. Dusev I.I. Svjaz' mezhdu geometricheskimi i kinematicheski-mi parametrami vysshej kinematicheskoj pary [The relationship between the geometric and kinematic parameters of the higher kinematic pair]. Izv. Severo-Kavkazskogo nauchnogo centra vysshej shkoly [News of the North-Caucasian Center of Higher Education]. 1973 , no. 3, pp. 28-32.

Received 17.05.2018

\section{Відомості про авторів / Сведения об авторах / About the Authors}

Ткач Павло Миколайович (Ткач Павел Николаевич, Tkach Pavlo Mykolayovych) - кандидат технічних наук (PhD in Eng. S.), доцент, Інститут електрозварювання ім. С.О. Патона НАН України, старший науковий співробітник відділу міцності зварних конструкцій; м. Київ, Україна; тел.: (050) 223-89-94; e-mail: pavlotkach78@gmail.com

Носко Павло Леонідович (Носко Павел Леонидович, Nosko Pavlo Leonidovych) - доктор технічних наук (Dr. habil. of Eng. S.), професор, Національний авіаційний університет, професор кафедри машинознавства; м. Київ, Україна; тел.: (050) 184-76-84; e-mail: nosko_p@ukr.net

Ревякіна Ольга Олександрівна (Ревякина Ольга Александровна, Revyakina Ol'ha Oleksandrivna) - кандидат технічних наук (PhD in Eng. S.), доцент, Луганський національний університет ім. Тараса Шевченка, доцент кафедри технологій виробництва і професійної освіти; м. Старобільськ, Україна; тел.: (050) 923-97-77; е-таil: olga.0509239777@gmail.com

Башта Олександр Васильович (Башта Александр Васильевич, Bashta Oleksandr Vasilyevich) - кандидат технічних наук, доцент (PhD in Eng. S.), Національний авіаційний університет, доцент кафедри машинознавства; м. Київ, Україна; тел.: (050) 137-99-70; e-mail: a.tower33@gmail.com

Корніснко Анатолій Олександрович (Корниенко Анатолий Александрович, Kornienko Anatoly Olexandrovich) - кандидат технічних наук (PhD in Eng. S.), доцент, Національний авіаційний університет, доцент кафедри машинознавства; м. Київ, Україна; тел.: (044) 406-78-42; e-mail: nau12@ukr.net

Tісов Олександр Вікторович (Тисов Александр Викторович, Tisov Olexandr Viktorovich) - кандидат технічних наук (PhD in Eng. S.), доцент, Національний авіаційний університет, доцент кафедри машинознавства; м. Київ, Україна; тел.: (044) 406-78-42; e-mail: nau12@ukr.net

Цибрій Юрій Олександрович (Цыбрий Юрий Александрович, Tsybri Yuri Olexandrovich) - кандидат технічних наук (PhD in Eng. S.), Національний авіаційний університет, кафедра машинознавства; м. Київ, Україна; тел.: (044) 406-78-42; e-mail: nau12@ukr.net 